\title{
PEDAGOGY
}

\section{ОСОБЛИВОСТІ РОЗВИТКУ КРИТИЧНОГО МИСЛЕННЯ ПІД ЧАС ПРОВЕДЕННЯ ДЕБАТІВ}

\author{
к.ф.н. Нечипоренко А. Ф., \\ к.п.н. Тільняк Н. В., \\ ст. викладач Сидоренко Л. М., \\ Украӥна, м. Київ, Начіональний технічний університет Украӥни \\ «Київський політехнічний інститут імені Ігоря Сікорського»
}

\section{DOI: https://doi.org/10.31435/rsglobal_ws/31032019/6414}

\section{ARTICLE INFO}

Received: 22 January 2019

Accepted: 26 March 2019

Published: 31 March 2019

\section{KEYWORDS}

debate,

critical thinking,

competence,

discussion,

educational process.

\begin{abstract}
The article discusses the method of "Debate" as an educational technology through the content of critical thinking. The significance of the debate for the development of critical thinking is analyzed; it turns out the effectiveness of their use for forming communicative competences of students in the process of teaching disciplines; the influence of the debate on increasing motivation and attracting students to the solution of the problems and the development of logical and critical thinking are researched.
\end{abstract}

Citation: Нечипоренко А. Ф., Тільняк Н. В., Сидоренко Л. М. (2019) Osoblyvosti Rozvytku Krytychnoho Myslennia pid Chas Provedennia Debativ. World Science. 3(43), Vol.3. doi: 10.31435/rsglobal_ws/31032019/6414

Copyright: (C) 2019 Нечипоренко А. Ф., Тільняк Н. В., Сидоренко Л. М. This is an open-access article distributed under the terms of the Creative Commons Attribution License (CC BY). The use, distribution or reproduction in other forums is permitted, provided the original author(s) or licensor are credited and that the original publication in this journal is cited, in accordance with accepted academic practice. No use, distribution or reproduction is permitted which does not comply with these terms.

Вступ. Метод «Дебати» одна 3 найдосконаліших освітніх форм, оскільки вона може бути використана під час вивчення будь-якої дисципліни де потрібно застосовувати комунікативні навички[1]. Також треба зазначити, що саме комунікативна компетенція допоможе сучасним студентам у їх кар'єрному зростанні, оскільки ефективні виступи перед колегами та клієнтами зможуть позитивно впливати на прийняття професійних рішень.

Дебати є важливим засобом пізнавальної діяльності студентів у процесі навчання. Вони значною мірою сприяють розвитку критичного мислення, дають можливість визначити власну позицію, формують навички відстоювати свою думку, поглиблюють знання 3 обговорюваної проблеми [3].

Сучасна дидактика визнає велику освітню і виховну цінність дебатів, оскільки вони сприяють глибокому розумінню проблеми, виробленню самостійної позиції, добору аргументів та оперуванню ними, розвиткові критичного мислення. Дебати, як одна 3 форм дискусії, навчають чути й розуміти співрозмовника, сприяють уточненню власних переконань, формуванню власного погляду на світ.

Результати дослідження. Дидактики відносять дебати як до методів навчання, так і до форм організації навчання. Дехто 3 фахівців вважає цей метод різновидом співробітництва, коли щодо обговорюваної проблеми висловлюються всі учасники спільної діяльності.

Щодо функцій дебатів у навчанні теж висловлюються різні погляди. Метод можна застосовувати на етапі засвоєння, закріплення або систематизації знань[2]. Крім того, дебати 
можна застосовувати як метод розвитку психічних функцій, творчих здібностей і особистісних якостей студентів, а також як метод їх стимулювання й мотивації.

Підготовка до дебатів і процедура їх проведення залежать від теми і мети заняття, рівня володіння студентами англійською мовою. Дебати - досить гнучка і зручна форма, оскільки в них може брати участь різна кількість студентів, а висловлювання розподіляються між учасниками відповідно до їх можливостей [4]. Більш активні і ініціативні студенти охоче вибирають роль спікера; студенти, не схильні до яскравих публічних виступів або недостатньо впевнені в своєму знанні мови, можуть брати участь у підготовці до дебатів, досліджувати проблему.

До вибору теми слід підходити особливо уважно, так як вона повинна бути актуальної i цікавою для студентів і в той же час пов'язана із загальною темою заняття. Під час занять стає зрозуміло, які теми студенти вважають цікавішими, які теми їх хвилюють, які розбіжності існують між учасниками суперечок. Студенти часто самі пропонують тему дебатів. Таким чином, можна визначити тезу або думку, яку частина студентів в групі безумовно підтримає, в той час як інша частина, швидше за все буде заперечувати [7].

Досвід використання дебатів у освітньому процесі дозволяє сформулювати деякі організаційно-педагогічні підвалини для їх проведення:

- дебати необхідно починати з постановки конкретного дискусійного питання (тобто такого, яке не має однозначної відповіді й допускає різні варіанти вирішення, зокрема протилежні);

- усі висловлювання мають не виходити за межі обговорюваної теми;

- кожне з висловлюваних тверджень повинне супроводжуватись аргументацією;

- дебати можуть завершитися як консенсусом (прийняттям узгодженого рішення), так і збереженням існуючих розбіжностей між учасниками дискусії [5].

Під час плануванні дебатів викладач враховує кілька важливих моментів: час, необхідний для ії проведення, місце, що забезпечує можливість здійснювати всі пересування учням, які дискутують, і стежити за дискутуванням решті учнів класу; матеріали, необхідні для роботи учнів та наочного подання ії результатів.

Щоб дебати були відвертими й демократичними, необхідно створити в групі атмосферу довіри та взаємоповаги. Студенти повинні знати правила ведення дебатів.

1. Висловлюватися слід почергово.

2. Не можна перебивати того, хто говорить.

3. Критикувати слід ідеї, а не осіб, які їх висловлюють.

4. Необхідно поважати всі висловлені думки (позиції).

5. Сміятися можна лише над жартами.

6. Не можна змінювати тему дебатів.

7. Потрібно заохочувати до участі в дискусії інших.

Використання методу дебатів розвиває критичне мислення студентів, змушує їх спілкуватися і взаємодіяти, покращує навички презентації, дослідження, командної роботи i ораторського мистецтва. Критична спрямованість мислення орієнтована на творчу і конструктивну діяльність, тому критичне мислення $\epsilon$ характеристикою мислення вільної особистості.

Значення дебатів у формування критичного мислення розглядали О. Фрілі i Д. Стейнберг. Перший розділ свого посібника «Аргументація і дебати: критичне мислення для аргументованого прийняття рішень» вони присвячують критичному мисленню, визначаючи його як вміння аналізувати, заперечувати й захищати ідеї; міркувати, застосовуючи індукцію і дедукцію, досягати висновків, що грунтуються на фактах або думках, але які базуються на надійних висновках, чітких твердженнях знань про цінності [8].

Критичне мислення означає мислення оціночне, рефлексивне. Це відкрите мислення, що не приймає догм, що розвивається шляхом накладення нової інформації на особистий життєвий досвід. В цьому і $є$ відмінність критичного мислення від мислення творчого, яке не передбачає оцінювання, а передбачає продукування нових ідей, які виходять за межі життєвого досвіду, зовнішніх норм і правил. Провести чітку межу між критичним і творчим мисленням складно. Можна сказати, що критичне мислення - це початок для розвитку творчого мислення.

Критичне мислення включає структуру умінь і структуру схильностей. Воно складається з наступних пізнавальних умінь: інтерпретація, аналіз, оцінка, висновок, пояснення 
i саморегуляція, які визначають його сутність [6]. Критично мисляча людина успішно застосовує вміння критичного мислення на різних заняттях і в повсякденному житті. навчання у формі самостійної або групової роботи учнів з наступним обговоренням їі результатів.

\section{Висновки.}

Отже, розвиток критичного мислення під час дебатів на практичних заняттях надасть такі можливості: поєднувати загальні, групові та індивідуальні форми організації навчального процесу; застосовувати сучасні методи навчання на різних етапах підготовки студентів; готувати до професійної мобільності майбутніх фахівців; отримати знання та вміння щодо розвитку критичного мислення. Саме розвиток критичного мислення під час обговорення спірних проблем сприятиме розвитку самостійності в прийнятті рішень, здатності до пошуку, аналізу та вирішення нестандартних ситуацій та до активізації розумової діяльності.

\section{ЛIТЕРАТУРА}

1. Освітні технології: Навч.-метод. посіб. / О.М. Пехота, А.З. Кіктенко, О.М. Любарська та ін., за ред. О.М. Пєхоти. - К.: Видавництво А.С.К., 2003.

2. Пометун О. І. Методика розвитку критичного мислення на уроках історії / О. І. Пометун // Історія і суспільствознавство в школах України: теорія та методика навчання - К.: Видавництво “Педагогічна пресса", 2012. — № 4. - С. 9.

3. Рубинштейн С. Л. Основы общей психологии: В 2 т. / С. Л. Рубинштейн. - М.: Педагогика, 1989. - T. 2. $-243 \mathrm{c}$.

4. Тягло А. В. Критическое мышление. Проблема мирового образования XXI века / Тягло А. В., Воропай Т. С. — Харьков: Ун-т внутр. дел, 1999. - 285 с.

5. Халперн Д. Психология критического мышления / Халперн Д. - 4-е Международное издание. С.-Пб.: Питер, 2000. - 512 с.

6. Шакирова Д. М. Теоретические основания концепции формирования критического мышления / Д. М. Шакирова // Педагогика. — 2006. — № 9. - С. 72-77.

7. Шнайдер, А. Навчання через дебати: різноманіття поглядів [Текст] / А. Шнайдер, М. Шнурер; [адапт. перекл. з англ.]. - К.: БФ «Вчителі за демократію та партнерство», 2009. - 320 с.

8. Freeley, A. J. Argumentation and Debate: Critical Thinking for Reasoned Decision Making [Text] / A. J. Freeley, D. L. Steinberg. - 12th ed. - Belmont, CA: Wadsworth, 2009. - P. 1-531. 